\title{
Coconut water enhances immunity of cockerels before and after vaccination against Newcastle disease virus
}

\author{
I. I. Bello ${ }^{1 *}$, A. A. Abdullah'², O. D. Adelakun ${ }^{1,3}$, O. A. Agbato ${ }^{4}$ and B. A. Okunrinkoya ${ }^{5}$ \\ ${ }^{1}$ Department of Animal Health and Production Technology, Oyo State College of Agriculture Technology, Igboora, Oyo \\ State, Nigeria. \\ 2Department of Biomedical Sciences, Faculty of Veterinary Scien, University of Gadarif, Gadarif- Sudan. \\ ${ }^{3}$ Department of Preventive Medicine and Public Health, University of Ibadan, Nigeria. \\ ${ }^{4}$ Federal College of Animal Health and Production Technology, Moor Plantation, Ibadan. \\ ${ }^{5}$ Department of Animal Health and Production Technology, Federal College of Agricultural Produce Technology, Kano, \\ Kano State, Nigeria. \\ *Corresponding author. Email: idribell2014@gmail.com; Tel: +234 8105093909.
}

Copyright (@ 2021 Bello et al. This article remains permanently open access under the terms of the Creative Commons Attribution License 4.0, which permits unrestricted use, distribution, and reproduction in any medium, provided the original work is properly cited.

Received 27th February, 2021; Accepted 22nd March, 2021

\begin{abstract}
Coconut water contains cytokinins and lauric acid which have potentials to enhance immune response. Poor immune response after vaccination is a common problem in poultry industry. Due to this challenge, this experimental study was carried out to evaluate the effects of coconut water on cell mediated and humoral immunity in cockerel chicks. Seventy five day-old cockerel chicks were randomly divided into three groups (A, B and C) and each group contained 25 birds. Group A (control) received ordinary water for 32 days while birds in group B received $100 \mathrm{ml}$ of coconut water/1 L of water for 32 days. Group $\mathrm{C}$ received $100 \mathrm{~mL}$ of coconut water/ $1 \mathrm{~L}$ of water till day 19 of age and ordinary water from day 20 to day 32 of age. The birds were vaccinated against Newcastle disease (NDV) on day 20. Blood samples were collected on day 19 and 32 to evaluate the leukogram, antibody titer against NDV, total proteins and cytokines. Intestinal samples were also collected for immunoglobulin $A$ analysis following the euthanasia of the birds. Means $\pm S D$ of the parameters were calculated and compared for significance differences using one-way ANOVA $(p<0.05)$. A significantly lower total protein and globulin levels were recorded in groups $B$ and $C$ on day 19. Contrarily, there was an increase in total protein and globulin levels in groups $B$ and $C$, and an increase in monocytes count in group B on day 32 . The serum levels of gamma interferon, interleukin 2 and Newcastle disease antibody titre increased significantly in groups B and C on day 32 . Immunoglobulin $\mathrm{G}$ and $\mathrm{A}$ concentrations were not significantly different across the three groups on day 32 . These results showed that coconut water supplementation before and after vaccination improved immune response to Newcastle disease vaccine.
\end{abstract}

Keywords: Coconut water, cytokines, leukocyte, Newcastle disease vaccine, total protein.

\section{INTRODUCTION}

Poultry birds like other animals are susceptible to infections which consequently caused diseases and attendant economic losses to poultry sector (Abdullahi et al., 2009). In Nigeria like other developing countries, there is predominance of Gumboro and Newcastle disease (ND) which continue to have negative effects on poultry production globally in spite of advancement made on vaccination (Alexander et al., 2012). Biosecurity and vaccination of birds remain the cheapest and effective means of preventing viral diseases in poultry flocks (Bosha and Nongo, 2012; Ramirez et al., 2013). Aside specific antibody, $\lg Y$ ( $\lg G$ in mammals), IgA and $\lg M$ antibodies are usually produced by birds as part of humoral immune response to vaccination (Jeurissen et al., 2000). The roles of these antibodies in immunity were associated with their capacity to neutralize Newcastle disease virus (NDV) (Al- 
Garib et al., 2003).

Apart from the humoral antibody, cell mediated immunity (CMI) is also a vital part of immunity. T lymphocytes are the principal cells of the CMI response and gamma interferon released by these cells played an important role in controlling the maturation and differentiation of numerous immune cells (Fensterl and Sen, 2009). Measurement of gamma interferon level in chicken is very useful in assessing CMI after vaccination or infection (Karaca et al., 1996; Breed et al., 1999). Interleukin 2 is also secreted by activated Th- 1 cells and dendritic cells (Nelson et al., 2004). Its role in CMI by enhancing activity of natural killer cells (Sakaguchi et al., 2008) and formation of immune memory cells (Malek and Raya, 2004) have been reported. The increased secretion of these antibodies and cytokines could alter serum total protein level. However, the importance of plasma protein in assessing immunity development against infections has been demonstrated (Oladele et al., 2005). There are reports on vaccine failure due to inability of birds to develop sufficient immunity after vaccination against diseases especially Newcastle disease virus (NDV). The common causes of vaccine failure as shown by previous studies include vaccine handling, storage (Bosha and Nongo, 2012), immune suppression, stress (Butcher and Yegani, 2008). In order to get sufficient immune response to NDV vaccines, adjuvants are commonly added to both inactivated (Yin et al., 2006) and live NDV vaccines (Hilton et al., 2002; Zhang et al., 2007). Also, the use of locally available dietary supplements such as lactobacillus-based probiotics (Sohail et al., 2010), Astragalus polysaccharide (Huang et al., 2008) and glycyrrhetenic acid liposome (Zhao et al., 2011) to boost immune response in chicken after vaccination has been established.

Coconut water is the liquid endosperm found at the centre of coconuts. It contains chemical constituents such as vitamins, amino acids, selenium, cytokinins (kinetin), minerals (Bhagya et al., 2010) and lauric acid. Antimicrobial properties of coconut water have been shown by different studies (Rajan et al., 2016; Rukmini et al., 2017). Kinetin was reported to have pro-proliferative effect on cells (Lee et al., 2006) and immune cells (Li et al., 2017). The immune-stimulatory (Prabhu et al., 2014) and anti-inflammatory (Christina et al., 2015) properties of coconut water have also been established.

Due to the poor immune response to vaccines (Xiao et al., 2009) and high prevalence of immunosuppressive diseases in Nigeria, there is need to look for locally available supplements that can boost immune response to vaccination. Coconut water is readily available in Nigeria and seems to be a promising immune booster because of its chemical constituents especially kinetin which can enhance immune response to vaccination. Unfortunately, the usage of coconut water as a supplement in poultry industry is still poorly harnessed

Therefore, this study was carried out to determine the immunity of chicken on coconut water supplementation before and after vaccination against NDV by assessing their leukogram, serum level of total proteins, immunoglobulins, $\mathrm{HI}$ antibody titers and cytokines.

\section{MATERIAL AND METHODS}

\section{Study design, place and duration}

This randomized control experimental study was carried out at the Poultry Unit of Teaching and Research Farm, Oyo State College of Agriculture and Technology between November 2019 and January 2020.

\section{Experimental birds}

Seventy- five day old cockerel chicks were obtained from a commercial farm in Ibadan, Nigeria. They were housed in clean and well-ventilated cages. The birds were given water and fed ad libitum.

\section{Source of coconut water}

Ripe coconut fruits (Cocos nucifera) were obtained from Igboora market, Oyo state and the fluid inside them was manually extracted for this study

\section{Experimental design}

The birds were randomly divided into three groups (A, B and $C$ ) of twenty five birds each. Group A (control) received ordinary water for 32 days while birds in group $B$ received $100 \mathrm{ml}$ of coconut water $/ 1 \mathrm{~L}$ of water for 32 days. The birds in group $C$ received $100 \mathrm{ml}$ of coconut water $/ 1$ $L$ of water till day 19 of age and ordinary water from day 20 to day 32 of age. All the birds were placed on the same feed regimen throughout the period of the experiment. At day 20 of age, the birds were vaccinated against Newcastle disease with LaSota strain (live attenuated vaccine) via their drinking water. The experimental protocols used in this study were in compliance with internationally accepted principles for animal use and care.

\section{Collection of blood and serum samples}

Fifteen birds in each group were bled on day 19 and 32 via wing vein puncture and the blood samples collected were transferred into EDTA vacuum tubes and plain vacuum tubes. Each EDTA tube containing blood was gently inverted 3 to 5 times to guarantee mixing of the sample with the anticoagulant, while the blood samples collected inside plain tubes were allowed to clot in order to get sera (Tuck et al., 2009). Thereafter, the sera were separated by centrifuge at 2000 to 3000 RPM for 20 minutes. 


\section{Bird sacrifice and intestinal sample}

At day 32 of the experiment, fifteen birds from each group were humanely slaughtered by euthanasia. To achieve euthanasia, $500 \mathrm{mg} / \mathrm{kg}$ body weight of phenobarbitone was administered to each bird via intravenous route (Igwebuike and Eze, 2010). The birds were carefully dissected with a scalpel blade to access the abdominal cavity and sections of duodenum were cut. The contents inside the intestinal samples were squeezed out and the samples were put inside separate organ bottles containing phosphate buffer solution (PBS). The tissues were homogenized in $1 \mathrm{ml}$ of PBS/100 mg of intestinal tissue.

\section{Leukogram, total protein and antibody titer against NDV analysis}

The procedure described by Samour (2006) was adopted to determine total and differential leucocyte counts. The total protein level in the serum was measured using biuret reaction, while colorimetric estimation of albumin level was determined using sigma diagnostic reagent (Sigma Diagnostic, UK) which contained Bromocresol Green (BCG). Serum globulin concentration was determined as the difference of total proteins and albumin (Van Wyk et al., 1998). The serum samples were tested for antibodies against NDV using standard haemagglutination inhibition test method. The antigen used was prepared from reconstituted commercial NDV Lasota vaccine. The principle of the test is based on the ability of serum samples in which antigen has been added to haemagglutinate washed red blood cells. The settling pattern of each serum was observed and antibody level of each serum sample was recorded as log base 2 .

\section{Cytokines analysis}

Serum concentrations of interleukin-2 and gamma interferon were determined by using ELISA- E0003Ch and E0013Ch (Bioassay Technology Laboratory, USA) respectively. The ELISA assay tests operates on the basis of competition between Streptavidin-Horseradish Peroxidase (HRP) conjugate and the interleukins in the sample for a limited number of binding sites on the antibody coated plate. The optical density (OD) was measured spectrophotometrically at a wavelength of $450 \mathrm{~nm} \pm 2 \mathrm{~nm}$. The OD value obtained for each sample is proportional to the concentration of IL-2. Serum concentrations of immunoglobilin $G$ and intestinal level of immunoglobulin $A$ were measured using immunoturbidi-metric assayBXC0701 and BXCO721 kits (fortress diagnostics, UK) respectively. The assay principle involved reaction between anti-IgA antibodies and IgA in the homogenized intestinal sample to form antigen-antibody complexes which were then measured turbidmetrically.

\section{Statistical analysis}

Data collected from this experiment were statistically analyzed with SPSS (Version 23) and differences between the means were tested with one-way ANOVA. The means were compared for significant differences at $p<0.05$ using Duncan's multiple range test, and the results from each group were presented as means \pm standard deviation (SD).

\section{RESULTS}

\section{Leukogram and serum total protein}

The total and differential leucocytes count in the birds across the three groups $A, B$ and $C$ at day 19 were not significantly different when compared. Except the monocyte count that increased significantly in group $B$, the total and other differential leucocyte counts in the three groups were not significantly altered when compared at day 32 (Table 1 ).

The total protein and globulin levels recorded at day 19 in groups $B$ and $C$ were lower when compared with values observed in group $A$. The albumin concentrations in groups $B$ and $C$ were not significantly different from the value observed in group $A$. Contrary to the trend observed at day 19 , the total protein and globulin concentrations in groups $\mathrm{B}$ and $\mathrm{C}$ on day 32 were higher and this increase was only significant when group $C$ was compared with group A. There was no significant difference in albumin levels recorded in groups $B$ and $C$ when compared with group A.

\section{Cytokine concentration}

The treatment groups B and C had significantly higher level of interleukin 2 and gamma interferon when compared with values recorded in group A. Also, the serum NDV antibody titre in groups $B$ and $C$ were significantly elevated when compared with the value observed in group A. Meanwhile, there were no significant change in the intestinal immunoglobulin $A$ level of treatment groups (B and $\mathrm{C}$ ) as compared with group $\mathrm{A}$ (Table 2).

\section{DISCUSSION}

The higher monocyte counts in group B on day 32 indicates the presence of strong cell mediated immunity in the group as a response to vaccination. The exposure of the group to coconut water might be responsible for this finding since kinetin, a major component of coconut water, has pro-proliferative effect on cells (Lee et al., 2006) and immune cells (Li et al., 2014). Reports have also shown 
Table 1. Leukogram and serum total protein levels in control and treatment groups

\begin{tabular}{lccc}
\hline Parameter & Group A & Group B & Group C \\
\hline Day 19 & & & \\
Total WBC $\left(\mathrm{mm}^{3} \times 10^{2}\right)$ & $126.00 \pm 9.69$ & $125.00 \pm 7.79$ & $125.00 \pm 7.27$ \\
Heterophil $\left(\mathrm{mm}^{3} \times 10^{2}\right)$ & $99.10 \pm 1.10$ & $94.50 \pm 8.39$ & $95.1 \pm 8.58$ \\
Lymphocyte $\left(\mathrm{mm}^{3} \times 10^{2}\right)$ & $24.90 \pm 2.52$ & $27.10 \pm 3.00$ & $27.30 \pm 2.04$ \\
Monocyte $\left(\mathrm{mm}^{3} \times 10^{2}\right)$ & $1.94 \pm 0.38$ & $2.26 \pm 0.28$ & $1.70 \pm 0.37$ \\
& & & \\
Day 32 & $119.00 \pm 5.29$ & $121.00 \pm 9.32$ & $105.00 \pm 4.63$ \\
Total WBC $\left(\mathrm{mm}^{3} \times 10^{2}\right)$ & $88.70 \pm 5.93$ & $89.00 \pm 6.64$ & $81.8 \pm 3.49$ \\
Heterophil $\left(\mathrm{mm}^{3} \times 10^{2}\right)$ & $29.27 \pm 2.06$ & $29.30 \pm 3.24$ & $21.7 \pm 2.46$ \\
Lymphocyte $\left(\mathrm{mm}^{3} \times 10^{2}\right)$ & $1.20 \pm 0.27$ & $2.50 \pm 0.30^{\mathrm{a}}$ & $1.83 \pm 0.28$ \\
Monocyte $\left(\mathrm{mm}^{3} \times 10^{2}\right)$ & & & \\
& & & \\
Day 19 & $68.60 \pm 1.74$ & $59.65 \pm 3.09^{\mathrm{a}}$ & $60.04 \pm 3.50^{\mathrm{b}}$ \\
Total Protein $(\mathrm{g} / \mathrm{L})$ & $28.13 \pm 2.98$ & $31.58 \pm 3.35$ & $30.94 \pm 3.36$ \\
Albumin $(\mathrm{g} / \mathrm{L})$ & $40.47 \pm 3.14$ & $28.07 \pm 2.75^{\mathrm{a}}$ & $29.10 \pm 3.09^{\mathrm{b}}$ \\
Globulin $(\mathrm{g} / \mathrm{L})$ & & & \\
& & & \\
Day 32 & $73.20 \pm 2.00$ & $14.30 \pm 0.60$ & $14.70 \pm 0.80$ \\
Total Protein $(\mathrm{g} / \mathrm{L})$ & $14.30 \pm 0.50$ & $67.00 \pm 1.80$ & $72.10 \pm 5.60^{\mathrm{b}}$ \\
Albumin $(\mathrm{g} / \mathrm{L})$ & $58.90 \pm 1.60$ & & \\
Globulin $(\mathrm{g} / \mathrm{L})$ & & & \\
\hline
\end{tabular}

andicates significant difference when group $B$ was compared with group $A$.

bIndicates significant difference when group $\mathrm{C}$ was compared with group $\mathrm{A}$.

Table 2. Concentration of cytokines and antibody against NDV in control and treatment groups at day 32.

\begin{tabular}{lccc}
\hline Parameters & Group A & Group B & Group C \\
\hline Serum & & & \\
Interleukin 2 $(\mathrm{ng} / \mathrm{L})$ & $28.09 \pm 0.97$ & $39.32 \pm 3.40^{\mathrm{a}}$ & $38.46 \pm 2.44^{\mathrm{b}}$ \\
$\operatorname{lgG}(\mathrm{g} / \mathrm{l})$ & $1.15 \pm 0.04$ & $1.08 \pm 0.02$ & $1.07 \pm 0.03$ \\
Gamma Interferon $(\mathrm{ng} / \mathrm{L})$ & $1.86 \pm 0.29$ & $4.93 \pm 0.93^{\mathrm{a}}$ & $4.66 \pm 0.79^{\mathrm{b}}$ \\
NDV Antibody titre & $56.00 \pm 16.01$ & $100.10 \pm 14.12^{\mathrm{a}}$ & $100.60 \pm 10.45^{\mathrm{b}}$ \\
& & & \\
Intestine & & & \\
$\operatorname{lgA}(\mathrm{g} / \mathrm{L})$ & $0.49 \pm 0.02$ & $0.55 \pm 0.04$ & $0.53 \pm 0.09$ \\
\hline
\end{tabular}

andicates significant difference when group $B$ was compared with group $A$.

bIndicates significant difference when group $C$ was compared with group $A$.

that elevated monocyte percentage in birds, especially after vaccination, indicated strong immunity (Green, 1999; Šimpraga et al., 2008).

The low concentrations of serum total protein and globulin in groups $\mathrm{B}$ and $\mathrm{C}$, and high albumin level in group $C$ on day 19 (pre-vaccination) is suggestive of lesser degree of infection in the groups relative to group $A$. The total protein concentration in birds is approximately $40 \mathrm{~g} / \mathrm{l}$ (Scanes, 2015) and globulin level in 3 days to 20 weeks old turkey has been shown to range between 9.97 to 28.2 $\mathrm{g} / \mathrm{dl}$ (Szabó et al., 2005). In contrast to the above figures, values of total protein and globulin recorded in this present study were higher and this is plausible as the birds were vaccinated late hence, they could have been exposed to natural infections. Infections in animals are accompanied by high serum total protein, elevated globulin and low albumin levels resulting from enhanced antibody secretion in response to infection (Orhue et al.,2005; Wamboi et al., 2020). Coconut water supplementation seemingly reduced susceptibility of birds in groups B and C to infection probably as a result of its antimicrobial properties (Rajan et al., 2016; Rukmini et al., 2017).

Generally, there is always an in increase in globulin level and serum total protein after vaccination (Šimpraga et al., 
2008; Al-Hussary and Kudair, 2010). Similar trend was also observed across the groups in this current study after vaccination (day 32). However, the higher globulin, total protein and Newcastle disease antibody titre level in groups on coconut water supplementation is indicative of enhanced immune response of the birds in the groups to vaccination. Interleukin 2 is an immune-stimulatory cytokine that promotes production of gamma interferon and proliferation of immune cells (Cha et al., 2010). The significantly higher concentrations of interleukin 2 and gamma interferon in groups $B$ and $C$ signal enhanced cell mediated immunity. These elevated cytokines level alongside with high Newcastle disease antibody titre accounted for the increase in serum total protein observed in the group B and C. Numerous studies in poultry have demonstrated that the measurement of chicken gamma interferon (Karaca et al., 1996; Breed et al., 1999) and antibody titre can be used to evaluate immunity in chicken after vaccination. Similar to the finding in this current study is the report that indicated significant increase in interleukin 2 and gamma interferon concentration in breast cancer cells treated with coconut water vinegar, a fermented product of coconut water (Mohamad et al., 2019).

In conclusion, the results of this study showed that coconut water supplementation strengthened immunity of birds before and after vaccination against NDV by reducing susceptibility to infection and promoting immunity. The addition of coconut water to drinking water of birds before/after vaccination or both is recommended to poultry farmers.

\section{CONFLICT OF INTEREST}

The authors declare that there is no conflict of interest.

\section{REFERENCES}

Abdullahi, U., Adamu, S., \& Ahmed, A. (2009). Investigating on some causes of poultry vaccination failure in Bauchi Metropolis and environs, Nigeria. Nigerian Journal of Experimental and Applied Biology, 14(1), 47-50.

Alexander, D. J., Aldous, E. W., \& Fuller, C. M. (2012). The long view: a selective review of 40 years of Newcastle disease research. Avian Pathology, 41(4), 329-335.

Al-Garib, S. O., Gielkens, A. L. J., Gruys, E., \& Kochi, G. (2003). Review of Newcastle disease virus with particular references to immunity and vaccination. World's Poultry Science Journal, 59(2), 185-200.

Al-Hussary, N. A. J., \& Kudair, I. M. (2010). Effect of vaccination on some biochemical parameters in broiler chickens. Iraqi Journal of Veterinary Sciences, 24(2), 59-64.

Bhagya, D., Prema, L., \& Rajamohan, T. (2010). Beneficial effect of tender coconut water on blood pressure and lipid levels in experimental hypertension. Journal of Cell and Tissue Research, 10(1), 2139-2144.

Bosha, J., \& Nongo, N. (2012). Investigating vaccine handling and administration in Makurdi metropolis, Benue state, Nigeria.
Paper presented at: Proceedings of 37th conference of Nigerian society of animal production (NSAP), University of Agriculture Makurdi, Benue State, Nigeria.

Breed, D. G. J., Schetters, T. P. M., Verhoeven, N. A. P., BootGroenink, A., Dorrestein, J., \& Vermeulen, A. N. (1999). Vaccination against Eimeria tenella infection using a fraction of E. tenella sporozoites selected by the capacity to activate $T$ cells. International Journal for Parasitology, 29(8), 1231-1240.

Butcher, G. D., \& Yegani, M. (2008). Investigating vaccination failure in poultry flocks. Institute of Food and Agricultural Sciences, University of Florida. Retrieved August 5, 2020 from https://edis.ifas.ufl.edu/vm136.

Cha, E., Graham, L., Manjili, M. H., \& Bear, H. D. (2010). IL-7+ IL-15 are superior to IL-2 for the ex vivo expansion of $4 \mathrm{~T} 1$ mammary carcinoma-specific $T$ cells with greater efficacy against tumors in vivo. Breast Cancer Research and Treatment, 122(2), 359-369.

Christina, Y. I., Ibrahim, M., \& Rifa'i, M. (2015). Polyherbal EMSA ERITIN blocks nuclear factor-Kappa B (NF-[kappa] B) and proinflammatory cytokines in irradiated mice. American Journal of Immunology, 11(1), 17-25.

Fensterl, V., \& Sen, G. C. (2009). Interferons and viral infections. Biofactors, 35(1), 14-20.

Green, R. A. (1999). Reference range for normal ostriches and rheas. In: Weiss, D. J., \& Wardrop, K. J. (eds.). Schalm's veterinary hematology, 6th edition. Ames: Lippincott Williams \& Wilkins. Pp. 987-999.

Hilton, L. S., Bean, A. G., \& Lowenthal, J. W. (2002). The emerging role of avian cytokines as immunotherapeutics and vaccine adjuvants. Veterinary Immunology and Immunopathology, 85(3-4), 119-128.

Huang, X., Hu, Y., Zhao, X., Lu, Y., Wang, J., Zhang, F., \& Sun, J. (2008). Sulfated modification can enhance the adjuvant activity of astragalus polysaccharide for ND vaccine. Carbohydrate Polymers, 73(2),303-308.

Igwebuike, U. H., \& Eze, U. U. (2010). Morphological characteristics of the small intestine of the African pied crow (Corvus albus). Animal Research International, 7(1), 11161120.

Jeurissen, S. H., Boonstra-Blom, A. G., Al-Garib, S. O., Hartog, L., Koch, G. (2000). Defense mechanisms against viral infection in poultry: a review. Veterinary Quarterly, 22(4), 204208.

Karaca, K., Kim, I. J., Reddy, S. K., \& Sharma, J. M. (1996). Nitric oxide inducing factor as a measure of antigen and mitogenspecific T cell responses in chickens. Journal of Immunological Methods,192(1-2), 97-103.

Lee, J. H., Chung, K. Y., Bang, D., \& Lee, K. H. (2006). Searching for aging-related proteins in human dermal microvascular endothelial cells treated with anti-aging agents. Proteomics, 6(4), 1351-1361.

Li, M., Ouyang, W., Wu, X., Zheng, Y., Wei, Y., \& An, L. (2014). Kinetin inhibits apoptosis of aging spleen cells induced by $D$ galactose in rats. Journal of Veterinary Science, 15(3), 353359.

Malek, T. R., \& Bayer, A. L. (2004). Tolerance, not immunity, crucially depends on IL-2. Nature Reviews Immunology, 4(9), 665-674.

Mohamad, N. E., Yeap, S. K., Abu, N., Lim, K. L., Zamberi, N. R., Nordin, N., Sharifuddin, S. A., Long, K., \& Alitheen, N. B. (2019). In vitro and in vivo antitumour effects of coconut water vinegar on 4T1 breast cancer cells. Food and Nutrition Research, 63, 1616-1627.

Nelson, A. J., Staines, W. R., \& Mcllroy, W. E. (2004). Tactile 
stimulus predictability modulates activity in a tactile-motor cortical network. Experimental Brain Research, 154(1), 22-32.

Oladele, S. B., Nok, A. J., Esievo, K. A. N., Abdu, P., \& Useh, N. M. (2005). Haemagglutination inhibition antibodies, rectal temperature and total protein of chickens infected with a local Nigerian isolate of velogenic Newcastle disease virus. Veterinary Research Communications, 29(2), 171-179.

Orhue, N. E. J., Nwanze, E. A. C., \& Akafor, A. (2005). Serum total protein, albumin and globulin levels in Trypanosoma brucei-infected rabbits: Effect of orally administered Scoparia dulcis. African Journal of Biotechnology, 4(10), 1152-1155.

Prabhu, S., Dennison, S. R., Mura, M., Lea, R. W., Snape, T. J., \& Harris, F. (2014). Cn-AMP2 from green coconut water is an anionic anticancer peptide. Journal of Peptide Science, 20(12), 909-915.

Rajan, D., Samanthi, G., \& Nasimuddin, S. (2016). A study on un-vitro antimicrobial activity of coconut water and coconut oil on Candida sp. World Journal of Pharmaceutical Sciences, 4(12), 266-268.

Ramirez, L. A., Arango, T., \& Boyer, J. (2013). Therapeutic and prophylactic DNA vaccines for HIV-1. Expert Opinion on Biological Therapy, 13(4), 563-573.

Rukmini, J. N., Manasa, S., Rohini, C., Sireesha, L. P., Ritu, S., \& Umashankar, G. K. (2017). Antibacterial efficacy of tender coconut water (Cocos nucifera L) on Streptococcus mutans: An in-vitro study. Journal of International Society of Preventive \& Community Dentistry, 7(2), 130-134.

Sakaguchi, S., Yamaguchi, T., Nomura, T., \& Ono, M. (2008). Regulatory $T$ cells and immune tolerance. Cell, 133(5), 775787.

Samour, J. (2006). Diagnostic value of haematology. In: Clinical Avian Medicine. Spix Publishing, Palm Beach, USA.

Scanes C. G. (2015). Protein metabolism. In: Sturkie's Avian Physiology, 6th edition. Waltham, MA: Academic Press, Elsevier Inc; Pp. 455-468

Šimpraga, M., Lukač Novak, I., Mazija, H., Štoković, I., \& Vojta, A. (2008). Hematological and biochemical parameters of ostriches after vaccination against Newcastle disease. Periodicum Biologorum, 110(1), 91-94

Sohail, M. U., ljaz, A., Yousaf, M. S., Ashraf, K., Zaneb, H., Aleem, M., \& Rehman, H., 2010. Alleviation of cyclic heat stress in broilers by dietary supplementation of mannanoligosaccharide and Lactobacillus-based probiotic: Dynamics of cortisol, thyroid hormones, cholesterol, C-reactive protein, and humoral immunity. Poultry Science, 89(9), 1934-1938.
Szabó, A., Mezes, M., Horn, P., Sütő, Z., Bázár, G. Y., and Romvari, R. (2005). Developmental dynamics of some blood biochemical parameters in the growing turkey (Meleagris gallopavo). Acta Veterinaria Hungarica, 53(4), 397-409.

Tuck, M. K., Chan, D. W., Chia, D., Godwin, A. K., Grizzle, W. E., Krueger, K. E., Rom, W., Sanda, M., Sorbara, L., Stass, S., \& Brenner, D. E. (2009). Standard operating procedures for serum and plasma collection: early detection research network consensus statement standard operating procedure integration working group. Journal of Proteome Research, 8(1), 113-117.

van Wyk, E., van der Bank, H., \& Verdoorn, G. H. (1998). Dynamics of haematology and blood biochemistry in free-living African whitebacked vulture (Pseudogyps africanus) nestlings. Comparative Biochemistry and Physiology Part A: Molecular \& Integrative Physiology, 120(3), 495-508.

Wamboi, P., Waruiru, R. M., Mbuthia, P. G., Nguhiu, J. M., \& Bebora, L. C. (2020). Haemato-biochemical changes and prevalence of parasitic infections of indigenous chicken sold in markets of Kiambu County, Kenya. International Journal of Veterinary Science and Medicine, 8(1), 18-25.

Xiao, C., Bao, G., \& Hu, S. (2009). Enhancement of immune responses to Newcastle disease vaccine by a supplement of extract of Momordica cochinchinensis (Lour.) spreng. seeds. Poultry Science, 88(11), 2293-2297.

Yin, J., Jin, H., Kang, Y., Xiao, C., Zhao, L., Li, X., Ding, Z., Yang, F., Zhu, Q., \& Wang, B. (2006). Efficacy of modified levamisole adjuvant on inactivated virus vaccine. Viral Immunology, 19(3), 525-535.

Zhang, X., Zhang, X., \& Yang, Q. (2007). Effect of compound mucosal immune adjuvant on mucosal and systemic immune responses in chicken orally vaccinated with attenuated Newcastle-disease vaccine. Vaccine, 25(17), 3254-3262.

Zhao, X., Fan, Y., Wang, D., Hu, Y., Guo, L., Ruan, S., Zhang, J., \& Yuan, J. (2011). Immunological adjuvant efficacy of glycyrrhetinic acid liposome against Newcastle disease vaccine. Vaccine, 29(52), 9611-9617. 